\title{
Why the Balanced Scorecard Fails in SMEs: A Case Study
}

\author{
Assistant Professor Dr. Nopadol Rompho \\ Department of Operations Management, Faculty of Commerce and Accountancy \\ Thammasat University, 2 Prachan Rd. Bangkok 10200, Thailand \\ Tel: 66-89-526-5464Ｅ-mail: nrompho@tu.ac.th
}

Received: April 14, 2011

doi:10.5539/ijbm.v6n11p39
Accepted: June 8, $2011 \quad$ Published: November 1, 2011

URL: http://dx.doi.org/10.5539/ijbm.v6n11p39

This research is sponsored by the Faculty of Commerce and Accountancy, Thammasat University

\begin{abstract}
Though studies abound for large organizations where use of the Balance Scorecard is quite common, literature focused on the uses and limitations of the Balanced Scorecard in small and medium-sized enterprises (SMEs) is difficult to find. To help fill the gap, this study was conducted using one SME that failed in its attempt to implement the Balanced Scorecard with the goal of ascertaining the cause of the failure of the Balanced Scorecard. Data was collected for this study via interviews and researcher observations. Two in-depth interviews were conducted, one with the manager-owner and one with the employee who is directly responsible for the design and implementation of the Balanced Scorecard. The researcher also observed and facilitated the design and implementation of the Balanced Scorecard in the company over the same period. The results reveal that frequent change in strategy was a major factor leading to the failure of the Balanced Scorecard in SMEs.
\end{abstract}

Keywords: Balanced scorecard, SMEs, Performance measurement system

\section{Introduction}

The Balanced Scorecard developed by Kaplan and Norton in 1992 (Kaplan and Norton, 1992) is one of the most widely used management tools today. It is implemented in many large organisations, including Mobile, Cigna (Kaplan and Norton, 1996; 2001; 2004), ABB, Scandia and Halifax (Olve et al 1999). A recent study found that 44 percent of organisations in North America (Rigby, 2001) and 35 percent of large US firms (Marr et al 2004) use the Balanced Scorecard. Studies conducted by Silk (1998) and Malmi (2001) also find that use of the Balanced Scorecard is widespread. Though found to be popular in large organisations, literature reporting on the uses and limitations of the Balanced Scorecard in small and medium-sized enterprises (SMEs) is rare. Most SMEs are not aware of this technique and the usage rate is very low compared to large organisations (Tennant and Tanoren, 2005). At the same time, the Balanced Scorecard is believed to be as beneficial for SMEs as it is to large organisations (McAdam, 2000; Andersen et al 2001; Kaplan and Norton, 2001).

The Balanced Scorecard is not without limitations. Many studies investigate the limitations of the concept in general (see, e.g., Butler et al 1997; Dinesh and Palmer, 1998; Epstein and Manzoni, 1998; Schneiderman, 1999; Norreklit, 2000; Aidemark, 2001; Heinz, 2001; Kennerley and Neely, 2002; Olson and Slater, 2002). However, there are very few studies that reveal the limitations of its application in SMEs, which may due to the limited application of this method in small organisations compared to large ones. This study attempts to fill the gap by investigating the limitations of implementing the Balanced Scorecard in SMEs.

The paper begins with the introduction of the Balanced Scorecard followed by reviews of the literature studying the implementation of the Balanced Scorecard in both large organisations and SMEs. Then the research methodologies are described, followed by the background of the case study for this research. Findings are then reported, along with the research and practical implications of this study. The paper closes with the conclusions.

\section{What is the Balanced Scorecard?}

The Balanced Scorecard is an approach developed by Professor Dr. Robert S. Kaplan from Harvard Business School and Dr. David P. Norton in the early 1990s. It first appeared in the article 'The Balanced Scorecard-Measures That Drive Performance' in the Harvard Business Review, in 1992 (see Kaplan and Norton, 1992). The Balanced Scorecard approach addresses some of the weaknesses and vagueness of previous management approaches. It attempts to provide a clear prescription as to what organisations should measure. It also translates vision and strategy, defines the strategic linkages to integrating performance across an organisation, communicates objectives and measures to a business unit, and aligns strategic initiatives. When fully implemented, it aligns everyone within an organisation so that all employees understand how and what they can do to support the strategy. It can also be used as a basis for compensation and provides feedback to management as to whether the strategy is working. The Balanced Scorecard suggests that an organisation's performance can be viewed from four main perspectives: financial, customer, internal business process, and learning and growth. These four perspectives are linked to the organisation's strategy and create a holistic model of its strategy that allows all employees to see how they can contribute to the success of the organisation. Figure 1 shows Kaplan and Norton's Balanced Scorecard framework. 


\section{Failure of the Balanced Scorecard in large organisations}

Despite many stories of successful implementation of the Balanced Scorecard in large companies, Kaplan and Norton (2001, p. 360), based on their experience of Balanced Scorecard implementation in many organisations, identify two sources of the failure of the Balanced Scorecard in large companies: the design and the process.

3.1 Design failure

A poorly designed Balanced Scorecard may lead to its failure in an organisation. A poor design includes:

- $\quad$ Too few measures in each perspective, leading to failure to obtain a balance between leading and lagging indicators or financial and non-financial indicators.

- Too many indicators without identifying the critical few: in this case, the organisation will lose focus and be unable to find linkage between indicators.

- $\quad$ Failure of measures selected to depict the organisation's strategy. This happens when an organisation tries to input all its Key Performance Indicators (KPIs) into each perspective without screening to select only those measures linked to its strategy. This means the organisation's strategy is not translated into action and it thus does not obtain any benefit from the Balanced Scorecard.

\subsection{Process failure}

Process failures are the most common causes of failure of the Balanced Scorecard and include (Kaplan and Norton, 2001, p. 361):

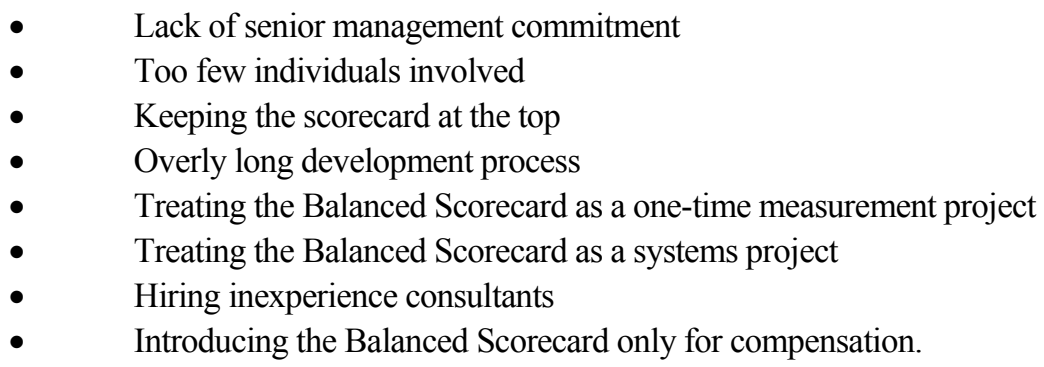

The underlying factor behind these failures is ineffective communication within an organisation. This means that not everyone in the organisation understands the concept and thus may even oppose it. The Balanced Scorecard is not a one-time project: It is a continual process. It translates strategy to operational terms, aligns the organisation to strategy, and makes strategy everyone's everyday job. All of these elements must be fully supported by senior management and the executive leadership is clearly required (Kaplan and Norton, 2001, p. 361).

\section{Implementation of the Balanced Scorecard in SMEs}

Although the study of performance measurement systems (PMS) has increased, literature covering PMS for SMEs is scanty (Hudson et al., 2001; Anderson et al., 2001). SMEs can clearly obtain value from PMS but there are significant barriers to implementation lying in resource limitations and the fact that it can be too strategically orientated (Hudson et al., 2001). In comparison with large organisations, SMEs are fundamentally different in three aspects: uncertainty, innovation, and evolution (Garenco et al. 2005). As a result, the PMS in SMEs is somewhat different than what is found in large organisations. It is argued that it is difficult to involve SMEs in performance measurement projects because of lack of time available or lack of top manager involvement (Tenhunen et al. 2001). SMEs also often implement only some parts of PMS or modify the models without carefully investigating the impact of such modification (CIMA, 1993). It is also found that SMEs rarely implement PMS as a holistic approach (Barnes et al. 1998; Rantanen and Holtari, 2000) and measures in their model are more focused on operational and financial performance and lack measures dealing with other areas (Addy et al. 1994; Chennell et al. 2000; Hudson et al. 1999).

Although there is some literature concluding that there is an absence of a balanced PMS model for SMEs or even that the Balanced Scorecard is not appropriate for SMEs (McAdam, 2000), the concept of the Balanced Scorecard has been used successfully in a number of small organisations that have employees ranging from about a dozen up to a couple of hundred (Kaplan and Norton, 2001, p. 369). There are also several studies reporting the use of this technique in SMEs (for example Hvolby and Thorstensen, 2000; Tenhunen et al 2001; Fernandes et al 2006; Bhagwat and Sharma, 2007; Manville, 2007). It is well recognised that the use of the Balanced Scorecard in SMEs is significantly different than that in large organisations. Although the steps needed in the design process are not very different, the duration of each step is much shorter in smaller organisations (Andersen et al 2001). The benefits gained from adopting the Balanced Scorecard are also different in the two types of organisations. Large organisations often gain more benefit from the effective communication of their strategy, while the SME gains more from the description of strategic objectives with priorities and the drive for a more effective strategic management process (Andersen et al 2001).

In order to implement the performance measurement framework successfully in SMEs, it has been suggested that only the most critical performance indicators be selected and utilised because SMEs have severely constrained resources (Hvolby and Thorstensen, 2000). The clarification of objectives for an SME is another important factor that can affect the success or failure of its performance measurement framework (Tenhunen et al 2001). Other important factors 
include support and commitment from the owner and manager, the main purpose of the PMS, support from employees (Tenhunen et al 2001), good cooperation between departments, and the use of standard hardware and software systems (Fernandes et al 2006).

Factors that can be obstacles to PMS implementation in SMEs are pointed out in numerous studies, and these include limited human resources (Noci, 1995), limited capital resources (Burns and Dewhurst, 1996; Ghobadian and Gallear, 1997; Neely and Mills, 1993), absence of supporting software (Bititci et al. 2002), lack of strategies resulting in short-term orientation (Brouthers et al. 1998), and no formalisation of the processes (Jennings and Beaver, 1997; Martins and Salerno, 1999).

Based on the review of available literature, most studies looked at only the implementation of a general PMS in SMEs and none specifically looked at the failure of the Balanced Scorecard when implemented. The factors described in most studies are often the critical success factors, meaning that SMEs that successfully implement the general PMS are likely to achieve all of these factors. Nevertheless the reverse is not always true, i.e. it is not guaranteed that success in all of these factors will lead to a successful use of the Balanced Scorecard in SMEs. This study therefore attempts to present another aspect of the Balanced Scorecard implementation, asking not why and how the Balanced Scorecard is successful in SMEs but rather why and how it fails in SMEs, a question little addressed in existing literature.

\section{Research methodology}

This study does not attempt to investigate factors that lead to the success of Balanced Scorecard implementation nor does it attempt to find the factors that lead to its failure. It argues, rather, that even if all the success factors reported in much of literature are achieved, the SME still can fail in its implementation of the Balanced Scorecard. This study therefore expands the boundary of knowledge of the Balanced Scorecard implementation in SMEs, by adding another important factor that SMEs should consider when implementing the Balanced Scorecard or any other performance measurement framework.

As the research objective is to answer the why and how, the case study approach was selected. In this study, a single case study is chosen instead of multiple case studies for four reasons. Firstly this single case study 'represents the critical case in testing a well-formulated theory' (Yin, 2003, p. 40). The case selected is chosen to test whether or not the factors reported in the literature that lead to successful Balanced Scorecard implementation are sufficient, i.e. with accomplishment of all these factors, whether SMEs can implement the Balanced Scorecard successfully. Secondly the case represents a unique case (Yin, 2003, p. 40). This case is very rare in view of the fact that not many SMEs are implementing the Balanced Scorecard and when they do so and fail, very few are willing to share their failure. Thirdly this is a revelatory case, in which the researcher 'has an opportunity to observe and analyse a phenomenon previously inaccessible to scientific investigation' (Yin, 2003, p. 42). In this study, the researcher was involved in setting up the Balanced Scorecard from the beginning. Finally this is a longitudinal case and therefore must be studied at two different points in time to discover how the conditions of interest change over time (Yin, 2003, p. 42).

Based on these four reasons, one Thai SME in the electrical appliance business was chosen as a case study. This company was selected from four that implemented the Balanced Scorecard and in which the researcher was involved from the beginning as a consultant. Compared against all the factors indicated in existing literature, three out of four were able to implement the Balanced Scorecard successfully. However the fourth, the one selected for the case study, failed in its implementation of the Balanced Scorecard. This was of great interest to the researcher since every step was similar to the other three and was carefully considered and the nature of the business was also very similar - but with dramatically different results.

Data was collected for study from interviews and researcher observation. Two in-depth interviews were conducted, one with the manager-owner and the other with the employee who was directly responsible for the design and implementation of the Balanced Scorecard. The researcher also observed and facilitated the design and implementation of the Balanced Scorecard in the company over the same period.

The main focus of the interviews and the observation was the factors critical for successful implementation of the Balanced Scorecard in large organisations and SMEs; these include design of the Balanced Scorecard, clarification of mission, senior management commitment and involvement of employees, communication process, development process, availability of time and resources, and uses of hardware and software system. These factors are based on what is found in existing literature on successful implementation of the Balanced Scorecard in both large organisations and SMEs.

The researcher recorded all of the data obtained from both interviews and observation and summarised the findings. The findings were then sent back to those interviewed to confirm accuracy of the conclusion as to what happened in their organisation. The interviewees agreed with the researcher's conclusion, confirming the validity of the data obtained in this study. The researcher then used this data for further analysis.

\section{The case study: SAQ Company Limited}

SAQ Company Limited was established in January 2002. It is a retail trading company in the electrical appliance sector. Its main product is air purifiers, in which it has the third largest market share in Thailand. The company has annual sales of over 10 million Thai Baht and has twelve full-time staff and a number of part-time staff depending on the season and marketing campaigns.

The drive for implementing the Balanced Scorecard came from the manager-owner. The main reason for his decision was that he saw a future for this business and expected rapid growth in the near future. He then looked for an 
appropriate performance measurement framework that could help him translate the organisation's mission and strategy into action and believed that the Balanced Scorecard would be of use in his organisation.

The researcher was invited to be a consultant to help set up the Balanced Scorecard for the company. The design stage lasted approximately four weeks. The first completed Balanced Scorecard was then put in place. Since then, meetings were held approximately once a month to discuss the measures in the Balanced Scorecard and the company's current strategies. Due to the changing environment and constant change in product characteristics, i.e. new product introduction, strategies were changed and many of the initial measures became obsolete. In some cases, data was not even collected for that specific measure before being discarded. Two years after implementing the Balance Scorecard, the manager-owner decided to stop using it until the company's strategy was more stable.

\section{Findings}

Using the results obtained from the interviews and observation, the factors critical for successful implementation of the Balanced Scorecard in large organisations and SMEs found in literature were identified, with results as shown in Table 1. This clearly shows that SAQ achieved all the factors critical for success as reported in literature - yet still failed in its implementation of the Balanced Scorecard. The interviews and observation revealed that the major cause for the failure was the company's frequent strategy changes. Since beginning to use the Balanced Scorecard, a number of measures were added or revised. This is in direct contrast with suggestions in the literature that in the context of emergent strategies, measures are largely unaffected and the only changes involve the launch of new initiatives (Kaplan and Norton, 2001, p. 370). This is obviously not the case in this company, in which the only measures unchanged were those pertaining to financial and learning perspectives, with most measures dealing with customers and the internal business processes needing to be revised. For example three months after launching the Balanced Scorecard, the company's sales declined because of a poor distribution channel. The company had sold its products to dealers who also carried competitor products for sale. This meant their dealers had no real motivation to push sales of SAQ's product. The manager-owner then decided to change the distribution channel, switching from dealers to superstores. The results were very impressive, with sales more than doubling the next month. However this change resulted in changes in several measures dealing with the customer perspective, for example from sales per dealer to sales per new distribution channel. The measures dealing with the internal business process were also changed to reflect the changes in customer perspectives. New measures reflecting the efficiency of the new channel distribution were added and previous measures relating to the previous channel (dealer) were abandoned.

It is found in this case study that the cause of the failure of the Balanced Scorecard would not be common in large organisations. The limitation of the Balanced Scorecard approach is specific to the nature of the SME business where response to market changes is more frequent than in a large organisation operating in much more stable market. In this case study, over a two-year period, the measures in the Balanced Scorecard were revised many times because of the strategy changes that were unavoidable in a rapidly changing business environment. This however created confusion among employees or even with the manager-owner. The frequent revision of the Balanced Scorecard meant that new data for the new measures must also be acquired. This made it impossible to track the cause and effect linkage between measures in the Balanced Scorecard and led to a waste of time and effort.

\section{Research and practical implications and limitations}

The findings in this study imply that although the Balanced Scorecard concept is found to be useful in many large organisations, care should be taken when it is implemented in smaller enterprises, where the nature of business is totally different. The findings of this case study expand the boundary of knowledge regarding implementation of the Balanced Scorecard, revealing that factors leading to successful use of the Balanced Scorecard in both large and small organisations as reported in existing literature, although necessary, are not sufficient to guarantee success. Frequent strategy changes that require revision of the Balanced Scorecard is another important factor that determines the success or failure of implementation.

However since this research was conducted using only one organisation as a case study, further research is obviously needed. The case study by nature is aimed at producing analytical generalisation, not statistical generalisation (Yin, 2003, p. 32). In order to achieve that aim, more case studies need to be conducted to find replication. For this research, more case studies of failure of implementation of the Balanced Scorecard in SMEs can be conducted to confirm that the frequency of strategy changes is one factor that may lead to failure. These cases attempt to 'predict similar results (a literal replication)' (Yin, 2003, p. 47). Alternatively, more successful cases can be investigated to learn whether they had only infrequent strategy changes. The aim is to 'predict contrasting results but for predictable reasons (a theoretical replication)' (Yin, 2003, p.47). In this study, theoretical replication to some extent was achieved because the researcher found that in three successful cases, strategies were not revised very often.

The results of this study may be useful for other SMEs that are implementing or about to implement the Balanced Scorecard, by aiding them in recognising potential limitations before investing more time and effort. The results also suggest that to implement the Balanced Scorecard, care should be taken, especially in the case of a newly established enterprise where strategy is still not well determined and likely to be changed significantly and frequently. These findings can be extrapolated to apply to other types of organisations, even large organisations that are operating in a rapidly changing environment. However further research in this area is needed in order to make the Balanced Scorecard more applicable to those organisations.

\section{Conclusion}

Although the Balanced Scorecard has been implemented in many large organisations successfully, little literature 
reports its use in SMEs (Andersen et al 2001). A number of studies also report its limitations; however these do not indicate limitations that are specific to SMEs by nature, where a rapid response to change is necessary and inevitable. This study therefore attempts to propose one important cause for failure of the implementation of Balanced Scorecard in SMEs: frequent strategy changes. It is also expected that this study will only be the beginning of more research in this area that will lead to the development of a more sturdy performance measurement framework for SMEs.

\section{References}

Addy, C., Pearce, J., \& Bennett, J. (1994). Performance measures in small manufacturing enterprises: are firms measuring what matters? In Proceeding of the 10th National Conference on Manufacturing Research. Loughborough, UK, 13- 15 September.

Aidemark, L-G. (2001). The Meaning of Balanced Scorecards in the Health Care Organisation. Financial Accountability \& Management, 17(1), 23-40. http://dx.doi.org/10.1111/1468-0408.00119

Andersen, H., Cobbold, I., \& Lawrie, G. (2001). Balanced Scorecard Implementation in SMEs: reflection in literature and practice. Proceedings of SMESME 2001 Conference, Denmark, Copenhagen, May 2001.

Barnes, M., Dickinson, T., Coulton, L., Dransfield, S.,Field, J., Fisher, N., Saunders, I., \& Shaw, D. (1998). A new approach to performance measurement for small to medium enterprises. In Proceedings of the Performance Measurement - Theory and Practice Conference, Cambridge, 14-17 July.

Bhagwat, R., \& Sharma, M.K. (2007). Performance measurement of supply chain management: A balanced scorecard approach. Computers \& Industrial Engineering, 53, 43-62. http://dx.doi.org/10.1016/j.cie.2007.04.001

Bititci, U.S., Turner, T., Nudurupati, S.S., \& Creighton, S. (2002). Web enabled measurement systems management implications. International Journal of Operations and Production Management, 22, 1273-1287. http://dx.doi.org/10.1108/01443570210450310

Brouthers, K., Andriessen, F., \& Nicolaes, I. (1998). Driving blind: strategic decision-making in small companies. Long Range Planning, 31, 130-138. http://dx.doi.org/10.1016/S0024-6301(97)00099-X

Burns, P., \& Dewhurst, J. (1996). Small Business and Entrepreneurship. London: Macmillan

Butler, A., Letza, S. R., \& Neale, B. (1997). Linking the balanced scorecard to strategy. Long Range Planning, 30 (2), 242-253. http://dx.doi.org/10.1016/S0024-6301(96)00116-1

Chennell, A., Dransfield, S., Field, J., Fisher, N., Saunders, I., \& Shaw, D. (2000). OPM: a system for organisational performance measurement. In Proceedings of the Performance Measurement - Past, Present and Future Conference, Cambridge, 19-21 July.

CIMA. (1993). Performance Measurement in the Manufacturing Sector. London: CIMA.

Dinesh, D., \& Palmer, E. (1998). Management by objectives and the balanced scorecard: will Rome fall again? Management Decision, 36(5/6), 363-369. http://dx.doi.org/10.1108/00251749810223529

Epstein, M., \& Manzoni, J. F. (1998). Implementing Corporate Strategy: From Tableaux de Bord to Balanced Scorecards. European Management Journal, 16(2), 190-203. http://dx.doi.org/10.1016/S0263-2373(97)00087-X Fernandes, K. J., Rajab, V., \& Whalley, A. (2006). Lessons from implementing the balanced scorecard in a small and medium size manufacturing organization. Technovation, 623-634. http://dx.doi.org/10.1016/j.technovation.2005.03.006

Garengo, P., Biazzo, S., \& Bititci, U. (2005). Performance measurement systems in SMEs: A review for a research agenda. International Journal of Management Reviews, 7(1), 25-47. http://dx.doi.org/10.1111/j.1468-2370.2005.00105.x

Ghobadian, A., \& Gallear, D. (1997). TQM and organisation size. International Journal of Operations and Production Management, 17, 121-163. http://dx.doi.org/10.1108/01443579710158023

Heinz, A. (2001). Applying the Balanced Scorecard Concept: An Experience Report. Long Range Planning, 34(4), 441-461. http://dx.doi.org/10.1016/S0024-6301(01)00057-7

Hudson, M., Bennett, J., Smart, P.A., \& Bourne, M. (1999). Performance measurement for planning and control in SMEs. In Proceedings of the Advances in Production Management Systems Conference - Global Production Management, Berlin, 6-10 September.

Hudson, M., Smart, A., \& Bourne, M. (2001). Theory and practice in SME performance measurement systems. International Journal of Operations \& Production Management, 21 (8), 1096-115. http://dx.doi.org/10.1108/EUM0000000005587

Hvolby, H-H., \& Thorstenson, A. (2000). Performance Measurement in Small and Medium-sized Enterprises. Proceedings of SMESME 2000 Conference, UK, Coventry, April 2000. ISBN 0905949862.

Jennings, P., \& Beaver, G. (1997). The performance and competitive advantage of small firms: a management perspective. International Small Business Journal, 15, 34-58. http://dx.doi.org/10.1177/0266242697152004

Kaplan, R. S., \& Norton, D. P. (1992). The Balanced Scorecard - Measures that Drive Performance. Harvard Business Review, 70(1), 71-89. PMid: 10119714

Kaplan, R. S., \& Norton, D. P. (1996). The Balanced Scorecard. Boston: Harvard Business School Press. 
Kaplan, R. S., \& Norton, D. P. (2001). The Strategy-Focused Organization. Boston: Harvard Business School Press.

Kaplan, R. S., \& Norton, D. P. (2004). Strategy Maps. Boston: Harvard Business School Press.

Kennerley, M., \& Neely, A. (2002). Performance measurement frameworks: A review. In: Neely, A., (Ed.) Business Performance Measurement: Theory and Practice, 145-155. Cambridge: Cambridge University Press. http://dx.doi.org/10.1017/CBO9780511753695.010

Malmi, T. (2001). Balanced scorecards in Finnish companies. Management Accounting Research, 12(2), 207-220. http://dx.doi.org/10.1006/mare.2000.0154

Manville, G. (2007). Implementing a balanced scorecard framework in a not for profit SME. International Journal of Productivity and Performance Management, 56(2), 162-169. http://dx.doi.org/10.1108/17410400710722653

Marr, B., Neely, A., Bourne, M., Franco, M., Wilcox, M., Adams, C., Mason, S., \& Kennerley, M. (2004). Business Performance Measurement - What is the State of Use in Large US Firms? Proceedings of PMA 2004 Conference, UK Edinburgh, July 2004, ISBN 0953376133.

Martins, R.A., \& Salerno, M.S. (1999). Use of new performance measurement system, some empirical findings. In Managing Operations Networks - VI International EurOMA Conference, Venice, Italy, 7-8 June.

McAdam, R. (2000). Quality models in an SME context: A critical perspective using a grounded approach. The International Journal of Quality \& Reliability Management, 17(3), 305. http://dx.doi.org/10.1108/02656710010306166

Neely, A.D., \& Mills, J.F. (1993). Manufacturing in the UK - Report on a Survey of Performance Measurement and Strategy Issue in UK Manufacturing Companies. London: Manufacturing Engineering Group.

Noci, G. (1995). Accounting and non-accounting based measures of quality-based performances in small firms. International Journal of Operations and Production Management, 15, 78-106. http://dx.doi.org/10.1108/01443579510090435

Norreklit, H. (2000). The balance on the Balanced Scorecard - A critical analysis of some of its assumptions. Management Accounting Research, 11(1), 65-88. http://dx.doi.org/10.1006/mare.1999.0121

Olson, E. M., \& Slater, S. F. (2002). The Balanced Scorecard, competitive strategy, and performance, Business Horizons, 45(3), 11-16. http://dx.doi.org/10.1016/S0007-6813(02)00198-2

Olve, N-G., Roy, J., \& Wetter, M. (1999). Performance Drivers. Chichester: John Wiley \& Sons.

Rantanen, H., \& Holtari, J. (2000). Performance analysis in Finnish SMEs. In Proceeding of the 11th International Working Seminar on Production Economics. Innsbruck, 21-25 February

Rigby, D. (2001). Management Tools and Techniques: A Survey. California Management Review, 43(2), 139-160.

Schneiderman, A. M. (1999). Why Balanced Scorecards Fail, Strategic Performance Measurement. Special Edition (January), 6-11.

Silk, S. (1998). Automating the balanced scorecard. Management Accounting, 79(11), 38-44.

Tenhunen, J., Rantanen, H., \& Ukko, J. (2001). SME-oriented implementation of a performance measurement system. Proceedings of the 13th International Society for Professional Innovation Management Conference, Finland, Lappeenranta, June 2001.

Tennant, C., \& Tanoren, M. (2005). Performance management in SMEs: a Balanced Scorecard perspective. International Journal of Business Performance Management, $7(2)$. http://dx.doi.org/10.1504/IJBPM.2005.006486

Yin, R. K. (2003). Case Study Research: Design and Methods, 3rd Edition. Thousand Oaks: Sage. 
Table 1. Results of study of critical success factors from interviews and observations

\begin{tabular}{|c|c|c|c|}
\hline \multirow{2}{*}{$\begin{array}{l}\text { Critical success } \\
\text { factor }\end{array}$} & \multirow[t]{2}{*}{ Suggestions from literature } & \multicolumn{2}{|c|}{ Results of study } \\
\hline & & Interviews & Observation \\
\hline $\begin{array}{l}\text { Design of the } \\
\text { Balanced } \\
\text { Scorecard }\end{array}$ & $\begin{array}{l}\text { Not too few or too many measures. } \\
\text { (Kaplan and Norton, 2001, p. 360). } \\
\text { There need to be only a few critical } \\
\text { indicators, since SMEs have a limited } \\
\text { amount of resources (Hvolby and } \\
\text { Thorstensen, 2000) }\end{array}$ & $\begin{array}{l}\text { Interviewees can recall } \\
\text { all current indicators in } \\
\text { the Balanced Scorecard, } \\
\text { suggesting that there are } \\
\text { not too many indicators. }\end{array}$ & $\begin{array}{l}\text { There are only twenty-four } \\
\text { measures in the four } \\
\text { traditional perspectives in the } \\
\text { Balanced Scorecard. The } \\
\text { number is in the range } \\
\text { suggested by Kaplan and } \\
\text { Norton (1996) }\end{array}$ \\
\hline $\begin{array}{l}\text { Clarification of } \\
\text { mission }\end{array}$ & $\begin{array}{l}\text { The mission of the organisation } \\
\text { should be clearly described (Kaplan } \\
\text { and Norton, 1996; 2001; Tenhunen et } \\
\text { al 2001) }\end{array}$ & $\begin{array}{l}\text { Interviewees can state } \\
\text { the mission of the } \\
\text { organisation correctly } \\
\text { and can explain how and } \\
\text { why this mission is } \\
\text { constructed. }\end{array}$ & $\begin{array}{l}\text { Mission and strategy are the } \\
\text { main issues in the monthly } \\
\text { meeting, hence it is } \\
\text { communicated clearly to all } \\
\text { employees. }\end{array}$ \\
\hline $\begin{array}{l}\text { Senior } \\
\text { management } \\
\text { commitment }\end{array}$ & $\begin{array}{l}\text { Senior management should fully } \\
\text { support the implementation of the } \\
\text { Balanced Scorecard (Kaplan and } \\
\text { Norton, 2001; Tenhunen et al 2001) }\end{array}$ & $\begin{array}{l}\text { Manager-owner is fully } \\
\text { committed. This is } \\
\text { supported by interviews } \\
\text { with employees. }\end{array}$ & $\begin{array}{l}\text { By conducting a meeting once } \\
\text { a month, especially for } \\
\text { updating the Balanced } \\
\text { Scorecard, it is clear that the } \\
\text { manager-owner is committed } \\
\text { to using this tool in his } \\
\text { organisation }\end{array}$ \\
\hline $\begin{array}{l}\text { Involvement of } \\
\text { employees }\end{array}$ & $\begin{array}{l}\text { Employees should be involved in } \\
\text { design and implementation stages } \\
\text { (Kaplan and Norton, 2001; Tenhunen } \\
\text { et al 2001; Fernandes et al 2006) }\end{array}$ & \multirow{2}{*}{$\begin{array}{l}\text { Interviewees indicated } \\
\text { that this is not the } \\
\text { problem because there } \\
\text { are only twelve } \\
\text { employees in this } \\
\text { organisation and } \\
\text { everyone has been } \\
\text { involved in every stage. }\end{array}$} & \multirow{2}{*}{$\begin{array}{l}\text { During the design and } \\
\text { implementation stage, every } \\
\text { employee was closely } \\
\text { involved. Suggestions were } \\
\text { always welcome and there } \\
\text { was no resistance from } \\
\text { employees at all. }\end{array}$} \\
\hline $\begin{array}{l}\text { Communication } \\
\text { process }\end{array}$ & $\begin{array}{l}\text { The Balanced Scorecard should be } \\
\text { communicated throughout the } \\
\text { organisation (Kaplan and Norton, } \\
\text { 2001) }\end{array}$ & & \\
\hline $\begin{array}{l}\text { Development } \\
\text { process }\end{array}$ & $\begin{array}{l}\text { The development process should not } \\
\text { be too long (Kaplan and Norton, } \\
\text { 2001) and should be clear and } \\
\text { resource effective (Hudson et al } \\
\text { 2001) }\end{array}$ & $\begin{array}{l}\text { Interviewees indicated } \\
\text { that the development } \\
\text { stage is fast and is not a } \\
\text { problem. }\end{array}$ & $\begin{array}{l}\text { The design and development } \\
\text { stage took only four weeks, } \\
\text { similar to what is given in the } \\
\text { literature (see Andersen et al } \\
\text { 2001) }\end{array}$ \\
\hline $\begin{array}{l}\text { Availability of } \\
\text { time and } \\
\text { resources }\end{array}$ & $\begin{array}{l}\text { Without enough time and resources, } \\
\text { the Balanced Scorecard cannot be } \\
\text { implemented successfully (Tenhunen } \\
\text { et al 2001) }\end{array}$ & $\begin{array}{l}\text { Interviewees believed } \\
\text { that necessary resources } \\
\text { are provided to make the } \\
\text { Balanced Scorecard } \\
\text { work and thus is not a } \\
\text { problem. }\end{array}$ & $\begin{array}{l}\text { There is a meeting every } \\
\text { month. One employee is also } \\
\text { solely responsible for the } \\
\text { analysis of the Balanced } \\
\text { Scorecard. Thus the lack of } \\
\text { time and resources is not a } \\
\text { major problem in this } \\
\text { organisation. }\end{array}$ \\
\hline $\begin{array}{l}\text { Uses of hardware } \\
\text { and software } \\
\text { system }\end{array}$ & $\begin{array}{l}\text { Appropriate uses of hardware and } \\
\text { software systems can help make } \\
\text { implementation of the Balanced } \\
\text { Scorecard successful. (Fernandes et al } \\
\text { 2006) }\end{array}$ & $\begin{array}{l}\text { Interviewees indicated } \\
\text { that only Microsoft } \\
\text { Excel is used for data } \\
\text { analysis and is good } \\
\text { enough for current } \\
\text { available data. }\end{array}$ & $\begin{array}{l}\text { There are not many indicators } \\
\text { in the Balanced Scorecard } \\
\text { thus little data is collected and } \\
\text { analysed. Only simple } \\
\text { calculations are enough at this } \\
\text { stage, therefore Microsoft } \\
\text { Excel is an appropriate data } \\
\text { analysis tool. }\end{array}$ \\
\hline
\end{tabular}




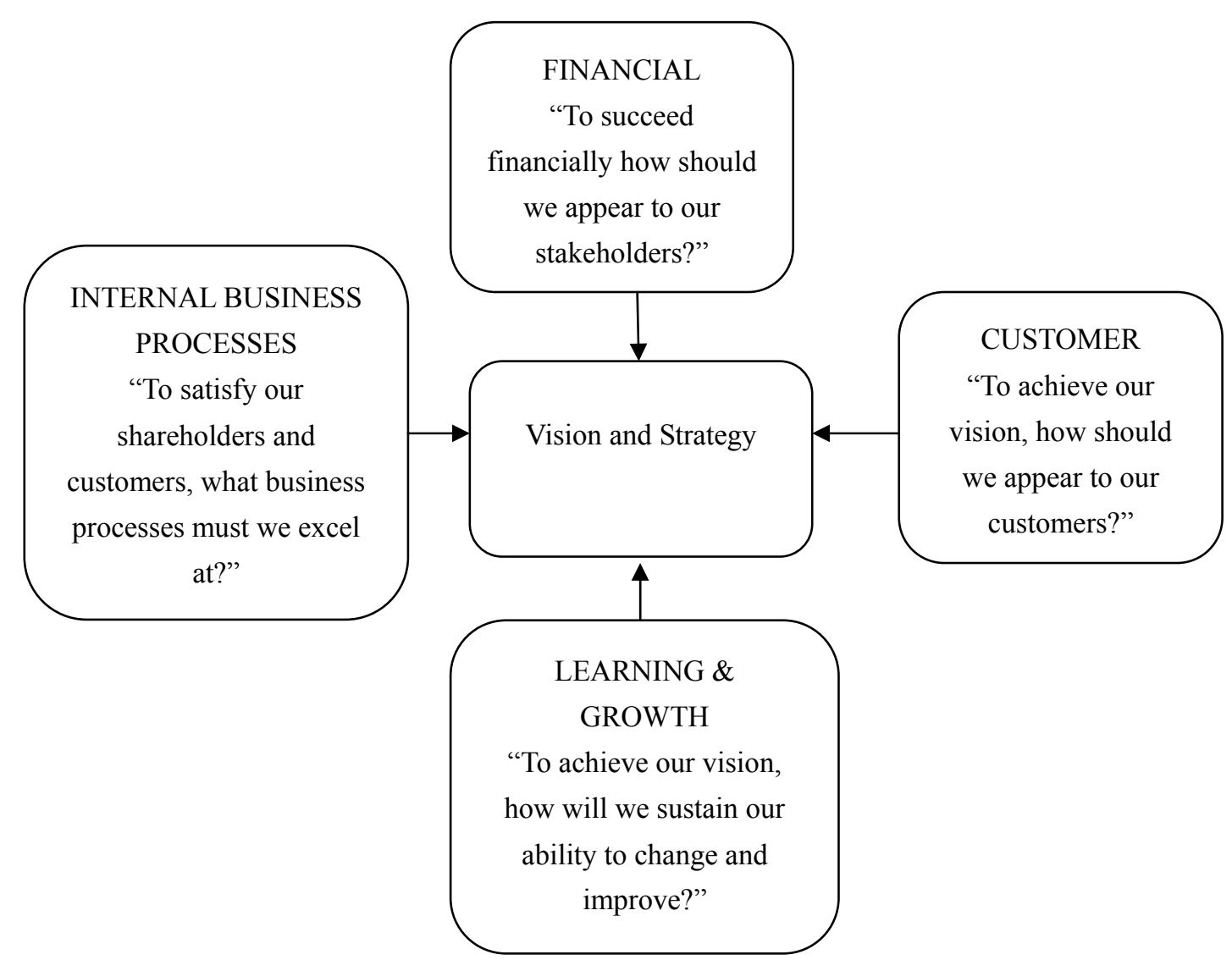

Figure 1. Balanced Scorecard framework (Kaplan and Norton, 1996) 